\title{
NYELVRŐL ÉS GONDOLKODÁSRÓL - EGY KÖNYV KAPCSÁN: NEUMER KATALIN (szerk.): NYELV, GONDOLKODÁS, RELATIVIZMUS*
}

\author{
JAKAB ZOLTÁN \\ Interdiszciplináris Szakterületei Intézete, Carleton Egyetem, Ottawa \\ Institute of Interdisciplinary Studies, Carleton University, Ottawa \\ E-mail: zjakab@ccs.carleton.ca
}

\section{BEVEZETÉS}

Sokoldalú és tartalmilag gazdag kötet Neumer Katalin és társai könyve, mely pszichológiai és filozófiai keretben elhelyezve elemzi a nyelvi relativizmus, valamint nyelv és gondolkodás összetett viszonyát. Mivel e mű nem tankönyvszerủ bevezető, olvasásához nem árt némi előismeret a kíséreti pszichológia, pszicholingvisztika, illetve nyelvfilozófia területéről. Előismeretek hiányában is emészthető azonban, csak talán kissé lassabban, mivel nagy információtartalmú, „sűrü” szövegről van szó. A kötet hat tanulmányából öt alapvetően filozófiai indítatású. A filozófiai problémák kapcsolódásait a pszichológiához, illetve az empirikusabb megközelítéshez Pléh Csaba tanulmánya elemzi.

A könyv vissza-visszatérő vezérgondolata a következőképpen foglalható össze. Abban a kérdésben, hogy meghatározza-e nyelvünk gondolkodásunkat, lényegében csak az '-e' kötőszócska jelentése vehető eleve adottnak. A helyes válasz e kérdésre tehát a visszakérdezés: mit értesz 'gondolkodás'-on? S mit értesz 'nyelv'-en? Ja igen, s mit értesz azon, hogy 'meghatároz'? A nyelv és gondolkodás közti viszony kérdése csak akkor válaszolható meg, ha a kulcsfogalmakat igen alapos elemzésnek vetjük alá; ekkor viszont a fő kérdés több részkérdésre bomlik.

Amellett, hogy az általános kérdések nem válaszolhatóak meg fogalmi elemzés nélkül, az empirikus, kísérleti adatok sem mondanak semmi érdekeset a nyelv és gondolkodás viszonyáról, ha ezt az elemzést nem végezzük el. Sőt, a tapasztalati

\footnotetext{
" Osiris Kiadó, Budapest, 1999, 322 oldal
} 
adatok relevanciája a filozófiai (vagy 'karosszék-pszichológiai') elméletek tekintetében egy külön probléma, mely független a nyelv-gondolkodás viszony tisztázásától. A megismeréstudomány egyik küldetése éppen a tapasztalati adatokra mutogató kísérletező pszichológusok és az ennek hatására vállukat vonogató filozófusok, illetve elméleti pszichológusok közti hídverés. Egyes, filozófiai hagyományon nevelkedett elméleti pszichológusok (vagy talán csak egyes filozófusok) szeretik hangsúlyozni, hogy tudományuk végső elméleti kérdései 'a prioriak', azaz itt pusztán fogalmilag megkonstruált elméleti lehetőségek összevetése a feladat, s ezért a tapasztalat, a kísérletek a végső kérdések szempontjából érdektelenek. S bár érzésem szerint ez az álláspont - legalábbis ami a pszichológiához kapcsolódó filozófiai kérdéseket illeti - alapvetően hamis, hamisságának megmutatása nem egyszerű feladat. E kérdés átfogó elemzésére e rövid írásban nem vállalkozhatom, de azért Pléh Csaba tanulmánya ürügyén egy példán bemutatom, miről is van szó. Ebben az áttekintőben nem követem a könyvben közölt tanulmányok sorrendjét, hanem attól kissé eltérően csoportosítom megjegyzéseimet.

\section{A RELATIVIZMUS ÉS UNIVERZALIZMUS FOGALMI MEGALAPOZÁSA WITTGENSTEIN KÉSŐI ÍRÁSAIBAN (NEUMER KATALIN)}

Neumer Katalin két tanulmányában elemzi az univerzalista és relativista szemlélet jelenlétét Wittgenstein késői írásaiban. Az első írás azt vizsgálja, hogy a nyelv és gondolkodás egységének tézise, valamint e két jelenség viselkedésközpontú elemzése milyen következményekkel bír a relativista tézis szempontjából. A második tanulmány a más kultúrák megértésének lehetőségéről vallott felfogást elemzi. Mindkettő végkövetkeztetése az, hogy bár Wittgenstein nyelvről és gondolkodásról alkotott felfogása utat nyit a relativizmus felé, ugyanakkor, felismervén annak korlátait, eljut egy univerzalista következtetéshez is.

A nyelv kiterjesztése minden viselkedéses megnyilvánulásra, illetve a gondolkodás kiterjesztése lényegében a lelki élet minden aspektusára, majd viselkedéses terminusokban való elemzésük legalább két elméleti akadályba ütközik, s ezek útjában állnak a szélsőségesen relativista világkép megalapozásának. Egyrészt az érzékleti élmények „belső realitása”, másrészt a külső valóság ellenáll a nyelvbe való teljes asszimilálásnak. Fájdalom és fájdalomviselkedés nem ugyanaz; érzékleteink nem lehetnek teljes egészében nyelvünk termékei. Ezenkívül némi reflexió után úgy tűnik, a tőlünk független világnak szintén van valamiféle beleszólása abba, hogy adott pillanatban használatos nyelvjátékaink megfelelőek, használhatóak vagy épp helytállóak-e.

DENNETT (1991) Wittgensteinéhez sok tekintetben hasonló utat követ a fájdalom és általában az érzékleti élmények elemzésében. Fájdalommal kapcsolatos egyik példája nagyjából a következő. Legyen adott két személy, Szl és Sz2. Tegyük fel, hogy Szl erős fájdalmat érez, de nagy az önuralma, s ezért csak mérsékelt hangerővel nyöszörög. Sz2 csak enyhe fájdalmat érez, de nincs sok önuralma, ezért éppúgy nyöszörög, mint Szl. Na mármost, van-e értelme arról beszélni itt, hogy a fenomenális fájdalomélmény nagyobb Sz1 esetében, mint Sz2-ében? Esetleg 
a fájdalomélmény, illetve a személy ahhoz való viszonya (mely döntően meghatározza a fájdalomviselkedést, azaz: ha úgy ítélem meg, hogy most valami elviselhetetlen történik, akkor jajgatok) nem is válik szét élesen. Fenomenális fájdalomélményről beszélni tehát problematikus dolog. Dennettnél az élmény belemosódik az ítéletbe, az ítélet pedig (gondoljunk az instrumentalista felfogásra) végső soron a viselkedésbe. $\mathrm{S}$ éppen a fenomenális élmény az, ami állítólag a problémát jelenti, mondjuk a wittgensteini érvelés számára. Dennettnek a következőt válaszolhatjuk: bár problémák vannak a fájdalomélmény, illetve egyéb, 'viselkedésközelibb' tényezők szétválasztásában, a különbségtétel mégis értelmesnek tűnik. Ha mondjuk Sz1 és Sz2 mindketten pókerarccal hallgatnak (nulla fájdalomviselkedés), attól még lehet, hogy Szl érez fájdalmat, Sz2 pedig egyáltalán nem. Ennek biztosan van értelme - fájdalom és fájdalomviselkedés tehát mégiscsak különböző dolgok.

Második tanulmányában Neumer Katalin Wittgenstein nézeteit elemzi más nyelvek és kultúrák megértésének lehetőségével kapcsolatban. Első közelítésben Wittgenstein álláspontja igen szkeptikusnak tűnik e kérdésben: a miénktől lényegesen eltérő kultúrákat egyszerűen nem érthetünk meg képviselöik viselkedése alapján. Ennél azonban árnyaltabb Wittgenstein véleménye: az úgynevezett közös emberi cselekvésmód az, ami a különböző kultúrák közötti átjárást biztosítja számunkra. A közös emberi cselekvésmód fogalmának többféle értelmezése is van Wittgensteinnél, s ezek közül csak az egyik felel meg e közvetítés céljára: a nyelvjáték jellegzetesen emberi tevékenysége. E cselekvésforma dialogikus, beszédcselekvés jellegű; a beszédcselekvések más cselekvésektől, illetve a környezetből nyerik jelentésüket; a szavak és cselekvések környezettel való összefüggése publikus szabályok által meghatározott. Ugyanakkor a szabálykövetés nem mereven meghatározott; az emberiség vagy egy adott kultúra „nagy nyelvjátéka” keretében megtörténő kisebb-nagyobb „nyelvi játszmák” a családi hasonlóság elve alapján kapcsolódnak egymáshoz. E szabály általi, de nem abszolút szigorú meghatározottság teret enged a közösség általi szabályozottság határmezsgyéjén lévő apró viselkedéssajátosságoknak, árnyalatoknak is. E szabályokkal pontosan meg nem ragadható, de nyelvhez kapcsolódó viselkedésszint elsajátítása a jelentésélmény megéléseként nyer értelmet a Wittgensteini felfogásban. (A jelentésélmény a nyelv intencionált aspektusa: az a különbség, ami valaminek a gondolva mondása, illetve papagájszerű elismétlése között van.) Az igazi megértéshez tehát a nyelvjáték együttcselekvés általi elsajátítása vezet - lényegében a másik kultúrához tartozó életforma átvétele. A nyelvelsajátítás e folyamata nem reflexív: a „nem leírom, hanem csinálom” elv érvényesül egy a miénktől eltérő nyelv megtanulásában.

\section{SZOKATLAN HASZNÁLAT ÉS MÁSOK MEGÉRTÉSE} (DARAB TAMÁS)

Darab Tamás elemzése Wittgenstein és Donald Davidson megértésről vallott felfogását elemzi, kimutatván, hogy a két, alapjaiban különböző felfogás a megértéssel és szokatlan szóhasználattal kapcsolatban igen hasonló végkövetkeztetésre jut. Davidson számára a relativizmus gondolata önellentmondás, mivel szerinte kü- 
lönböző világképek feltételezése csak akkor értelmes, ha létezik valamely végső közös keret, koordinátarendszer, melyben e világképek értelmezhetőek. Wittgenstein ezzel szemben nem látott ellentmondást a miénktől mélységesen, lényegileg különböző fogalmak gondolatában, melyeket akár nem is vagyunk képesek megérteni. Alapvető különbség a két szerző megközelítése között, hogy Wittgenstein a szójelentést viselkedési kategóriák segítségével elemzi, Davidson ellenben az igazságfeltéletek fogalmára vezeti vissza a jelentés problémáját. ${ }^{1}$

Mások megértése szempontjából központi jelentőségű az úgynevezett szokatlan szóhasználat megértése. A szokatlan használat sokféle lehet. Metaforikus szóhasználat (amikor például az aljas embert patkánynak nevezzük); egyéni élmény alapú szóhasználat (mikor azt mondjuk, hogy a hét napjainak különböző színük van); a műveletlen ember hibás szóhasználata (amikor napjaink hőse rádiótelefonján „koncenzusra” jut üzlettársával); sőt akár teljesen önkényes használat is, mondjuk amikor a 'leejt' szót valaki az elolvas értelmében használja, és hasonlók. Kérdés, hogyan magyarázható meg ezen esetek megértése a formális nyelvek számára konstruált Tarski-féle igazságelméletből kiindulva; Davidson ugyanis ezt az elméletet használja kiindulásul a természetes nyelvek jelentéselméletének kidolgozására. A hibás vagy önkényes szóhasználat az, amely hallgatója számára közvetlenül nem érthető meg az addig tanultak alapján. Davidson javasolt megoldása saját megértés- és cselekvéselméletének összekapcsolásából alakul ki. A beszélő által az adott pillanatig kialakított megértési sémák állandó módosítására van szükség a szokatlan használat változatos formáinak megértéséhez. Szétválik tehát a megértés kétféle, beszélők által használt elmélete. Az első egy úgynevezett kiinduló elmélet (prior theory), mely nem feltétlenül közösségi jellegű, s alapvetően az igazságfeltételek ismeretéhez kötött. A második az átmenetelmélet (passing theory), mely a beszédpartner szándékait is figyelembe veszi. Ez fontosabb a megértéshez, mint a kiinduló elmélet; ismerete nem nyelvi ismeretek függvénye, hanem a nyelvtől független cselekvéseké, azok megértéséé. Ugyanakkor nem adható meg szigorú szabály egy ilyen átmenetelmélet kidolgozására, éppen azért, mert nyelvismeret és a világban való eligazodás határa egybemosódik.

Hasonlóan Wittgenstein nyelvjáték, illetve életforma fogalmához - juthat eszünkbe. Ebből adódik a meglepő következmény: Wittgensteinhez hasonlóan Davidsonnál is lényegében megmagyarázatlan a szokatlan szóhasználat megértése. Ha ez így van, akkor hogyan magyarázzuk meg általában mások megértésének jelenségét? Hogyan ad számot Davidson elmélete a közös koordináta-rendszerről, melyet kiindulásképp szükségesnek minősített a különbözőség értelmezéséhez? Azaz: a relativizmus Davidson szerint ellentmondásos eszme, ám ha nem tudjuk megmagyarázni, hogyan lehetséges mások megértése, akkor hogyan tér ki az elmélet a csapdának minősített relativizmus elől?

Érdemes párhuzamba állítani Neumer és Darab Wittgenstein-rekonstrukcióját,

\footnotetext{
1 Igen röviden: Davidson szerint állítás jellegű nyelvi közléseink jelentését az határozza meg, hogy milyen körülmények között elhangozva lesznek igazak. Egyéb nyelvi közlések jelentése az állításokéból származik: az állítások szerepe elsődleges Davidson rendszerében. A „Csukd be az ajtót” felszólítást például Davidson rendszerében úgy elemezhetjük, hogy „Utasítalak. Becsukod az ajtót”. Jól érthető bevezetőt tartalmaz erről STAINTON (1996, 92-96).
} 
mivel érdekes különbség fedezhető fel közöttük. Neumer szerint (lásd az előző részt) az együttcselekvés igazi, maradéktalan megértéshez vezethet el; az életformaátvétel implikálja a nyelv tökéletes elsajátítását. Itt válik szét kettejük értelmezése.

Neumer szerint a nyelv tökéletes elsajátítása implikálja a szabályozottság határmezsgyéjén lévő finom viselkedésárnyalatok elsajátítását is, s e viselkedésárnyalatok pedig (lásd a 223. oldalt) a jelentésélmény fogalmának elemzéseként szolgálnak. Egyszóval a résztvevő együttcselekvés az életforma átvételen keresztül a jelentésélmény átvételéhez is szükségképp elvezet.

Darab azonban nem említi a jelentésélmény effajta elemzésének lehetőségét, és így nála a jelentésélmény a viselkedésben lehorgonyzatlan marad. (Talán a fájdalomélményhez válik hasonlóvá? - lásd Neumer első tanulmányát.) Ekkor a nyelv tökéletes elsajátítása együttcselekvés révén nem fogja implikálni a jelentésélmény átvételét. Úgy tűnik számomra, hogy Darab e megközelítés melletti érvként hozza fel a jelentésvakság Wittgenstein sugallta logikai lehetőségét, további empirikus alátámasztásként pedig azt, hogy jelentésvakok a való világban is léteznek, nézzük csak meg az autistákat. Darab Neumeréval ellentétes végkövetkeztetése: az együttcselekvés csak a tökéletes nyelvelsajátításnak, de nem a másik tökéletes megértésének biztosítéka. Az életforma elsajátítása nem szükségképp foglalja magában a jelentésélmény átvételét.

Érdemes észrevenni, hogy bár Neumer verziója nem használja érvként a jelentésvakság lehetőségét, végkövetkeztetése mégsem mond ellent e lehetőségnek. Neumer saját rekonstrukciója védelmében azt mondhatná, hogy ha létezhet is jelentésvak, az nem tud maradéktalanul elsajátítani semmilyen életformát. Csak a merevebben szabályozott nyelvjátékszintre érzékeny; e szintet elsajátítván látszólag elsajátít életformákat. A finom viselkedésárnyalatokra a jelentésvak nem érzékeny; ámde e viselkedésárnyalatok, melyek egyben a jelentésélményt adják, részei az életformának.

Végül pár szót az autistákról. Világosnak tűnik számomra, hogy az autisták és a jelentésvakok azonosítása mint feltételezett „empirikus evidencia”, nem játszik túl nagy szerepet Darab érvelésében, mégis érdemes megjegyezni, hogy ez az azonosítás alighanem elhamarkodott. Az autizmus egy erős elméleti felfogás szerint speciálisan a társas viselkedés deficitje, mely egy feltételezett 'elme-elméleti modul' működészavarából, a másoknak való lélektaniállapot-tulajdonítás képtelenségéből fakad. Az autistákra ezzel összhangban igaz az, hogy társas viselkedésük többnyire igen súlyosan sérült; e sérülés messze túlmegy valamiféle finom viselkedésárnyalatok hiányán. A legtöbb autista társas viselkedése első látásra sem tủnik problémamentesnek. Ugyanakkor a tárgyi világgal kapcsolatos viselkedéses-kognitív teljesítmények autistáknál sokkal kevésbé érintettek; bármi is legyen a jelentésélmény, a tárgyi világ vonatkozásában az autisták jó része alighanem rendelkezik ilyennel. Tehát, Wittgenstein fogalmai alapján, a szociális szférát tekintve az autista több, mint jelentésvak, a tárgyi világhoz való viszonyt tekintve pedig érzésem szerint nem jelentésvak. ${ }^{2}$

\footnotetext{
2 Nehézzé teszi e kérdés megvitatását az, hogy az autizmusnak fokozatai, enyhébb, illetve súlyosabb
} változatai vannak. Amit a főszövegben mondtam, az talán inkább az autizmus enyhe formáira áll. 


\section{BEFOGADJA AVAGY KIREKESZTI NYELVÜNK A MIÉNKTŐL ELTÉRŐ VILÁGKÉPEKET? (JEFF BERNARD)}

Tanulmányában Jeff Bernard Ferruccio Rossi-Landi olasz marxista szemiotikus nyelvi relativizmusról írott könyvét (Ideologies of Linguistic Relativity) megvizsgálva elemzi Benjamin Lee Whorf nyelvi relativista felfogását. Whorf, mint tudjuk, különböző természetes nyelvek szerkezeti különbségeit megfigyelve arra a következtetésre jutott, hogy a mélyreható nyelvi különbségek eltérő fogalmi szerveződéseket, és ezen keresztül eltérő gondolkodásmódokat eredményeznek különböző nyelvek beszélőinél. Egy adott nyelv szerkezeti vonásai bizonyos világképeket támogatnak, másokat nem, s ezzel beszélőiket mintegy a megfelelő világnézet ketrecébe zárják.

Ez a gondolatmenet úgy is értelmezhető, hogy a relativizmus figyelmen kívül hagyja a nyelv egyetemes tényezői aspektusát, a langage-t. Nincsenek univerzálék; a nyelv olyan fogalom, mint a játék Wittgenstein elemzésében. Nincsenek érdemi közös vonások, melyek minden (emberi, természetes) nyelvre és csak a nyelvekre jellemzőek, szól az implicit tézis. A nyelvi rendszer fogalma tehát kimerül a langue aspektusában, az egyedi természetes nyelvben.

E nézet kritikáját legalább három irányból indíthatjuk el; mindháromról volt már szó. Az első a realizmus kérdése: a világ nyelvünktől függetlenül az marad, ami. Neumer Katalin első tanulmányából láttuk, milyen elméleti következményei vannak a radikális antirealizmusnak. A második probléma már szintén ismert: ha nyelv és gondolkodás fogalmait elemezni kezdjük, a whorfi tézis kezdeti meggyőző ereje gyorsan szertefoszlik, legalábbis lecsökken. A harmadik probléma az, hogy, mint láttuk, a természetes nyelvek alapvetően nem akadályokat állítanak a gondolatok kifejezése útjába, hanem közvetlenül vagy kerülő úton támogatják mindenféle gondolat kifejezését. Bár a kínai nyelv nyelvtana bonyolulttá teszi a tényellentétes állítások kifejezését, ilyen állításokat mégis elgondolnak a kínaiak is. $\mathrm{S}$ hiába nem támogatják a részecske-mező világképet az európai nyelvek (szemben mondjuk a hopi nyelvvel), a modern fizika mégis alapvetően e nyelvek beszélőinek fejében született meg.

Elméletibb síkra váltva, a Rossi-Landi-féle érv szerint a relativizmus által hanyagolt langage aspektus az egyedi természetes nyelvi rendszer (langue) plusz a közös beszéd eredménye lehet csak. A whorfiánus relativisták ott tévednek, hogy az adott természetes nyelvi rendszerek mellé csak az elsajátítás passzív folyamatát tételezik fel. A közös beszéd során a langue módosulhat is, mintegy kiterjeszti önmagát, befogadván új, mondjuk addig abban a nyelvben még nem kódolt gondolati tartalmakat is. Ez a langue önkiterjesztő ereje, mely végül elvezet az egyetemes nyelvi jegyekhez, a langage szinthez is. Kissé elcsépeltebb fordulattal úgy is mondhatnánk, nyelvünk nem kirekeszt, hanem befogad új, addig ismeretlen gondolati tartalmakat; világkép szempontjából a nyelvek nyitottak.

Ilyenkor a társas viszonyok megértésének nehézsége/képtelensége, mely társas helyzetekben hamar észrevehető viselkedésdeficitet eredményez, együtt létezik a tárgyi világ lényegében normális szintű megértésével. 


\section{A TAPASZTALATI ADATOK RELEVANCIÁJÁNAK KÉRDÉSE}

Pléh Csaba tanulmányának bevezető része arra hívja fel a figyelmet, hogy 'gondolkodás' és 'nyelv' elemzetlen - vagy nem megfelelően elemzett - kategóriái hozzáférhetetlenek maradnak a tapasztalati kutatás számára. Világosan kiderül Pléh Csaba tanulmányából az is, hogy a tapasztalati adatok támogatják az univerzalista következtetés egy elég erős formáját, anélkül persze, hogy a nyilvánvalót, a mélyreható nyelvi-kulturális különbségek létét bármilyen formában cáfolnák. Ha úgy tesszük fel a kérdést, hogy vannak-e a megismerésnek olyan szintjei, aspektusai, melyek a nyelvtől független fejlődési utat képviselnek, akkor a válasz egyértelműen igen. Az észleléses kategorizáció, alakészlelés, a tér észleléses reprezentációja alapvető példái a nyelvfüggetlen fejlődésnek. E nyelvfüggetlenség ugyanakkor együtt létezik a feldolgozás későbbi szintjén megjelenő nyelvi visszahatásokkal.

Ami nyelvtan és logikai forma viszonyát illeti, a mai domináns koncepciók lényegében mindegyike univerzalista kiindulású (például a Fodor-féle elmenyelvfelfogás, vagy Jackendoff, illetve Lakoff elgondolásai a kognitív elsőbbségről). E tendencia az analitikus nyelvfilozófia kezdetéig nyúlik vissza. Frege logikai és szemantikai elmélete nem igazán eredeztethető a német nyelv grammatikai szerkezetéből. Bertrand Russell elmélete a deskripciókról szintén alapvető felismerésként tartalmazza a mondatok nyelvtani és az általuk kifejezett állitások (propozíciók) logikai formájának szétválását (bevezetőként lásd erről STAINTON, 1996, 48-50; bőségesen tárgyalja Russell elméletét NEALE, 1990). Bár Frege és Russell felfogása a szemantikáról, illetve a propozíciók természetéről alapjaiban tért el, nyelvtani és logikai forma függetlenségében egyetértettek.

Az egyetemes tényezők a nyelvelsajátításban is megmutatkoznak: a gondolkodás nyelv általi meghatározottságát a mai bevett felfogások lényegében egyike sem tételezi fel. A nyelv elsajátítását e felfogások egyrészt az általános kognitív rendszer teljesítményének tartják (mint Piaget vagy újabban G. Lakoff), illetve a nyelvi rendszer modularizált önfejlődését hangsúlyozzák (mint a Chomsky-követők); esetleg e két tényező együtthatását feltételezik (pl. S. Pinker).

Végül szeretnék bemutatni egy példát, mely talán rávilágít arra a relativizmus kérdésétől független problémára, mely a tapasztalati adatok és nyelvfilozófiai elméletek kapcsolatát jellemzi. Röviden: minden tapasztalati adat értelmezés útján kapcsolódik a különféle elméletekhez; minél elvontabb, általánosabb azonban egy elmélet, annál tágabb tere van arra, hogy az igazsága szempontjából releváns tapasztalati adatokat többféleképp értelmezve fenntartsa saját plauzibilitását. Több az elméleti kibúvó lehetősége; szó sincs azonban arról, hogy az elvontság egyenlő lenne ködös, üres általánosságokkal. A nyelvfilozófiának a pszichológia szempontjából érdekes elméletei igen részletesen kidolgozottak, és nem éppen semmitmondóak. Sok példát lehetne itt említeni; elégedjünk most meg eggyel.

A nyelvfilozófia egyik vissza-visszatérő tézise szerint csak mondatok (esetleg még nagyobb nyelvi egységek, pl. egész elméletek) bírnak pontosan meghatározható jelentéssel. A mondat alatti egységek, elsősorban a szavak jelentése az, amivel hozzájárulnak a mondatok jelentéséhez; továbbá van okunk azt gondolni, hogy ez a valami alapvetően helyzetfüggő, azaz meghatározatlan/meghatározhatatlan. E té- 
zis G. Frege szemantikai elméletéig nyúlik vissza (FreGE, 1978; DumMETT, 1981, 360). Frege kontextuselve szerint a szavak csak mondatok kontextusában rendelkeznek jelentéssel. Ahhoz, hogy megadjuk egy szó jelentését, említenünk kell azon mondatokat, melyekben a szó megjelenhet. W. O. Quine állítása szerint (QUINE, 1960) intuitív jelentésfogalmunknak egyszerủen semmi sem felel meg a világban. Még mondatok esetében is reménytelen a jelentés specifikálása, és nincs olyan, pontosan megadható, egyedi dolog, 'amivel a szavak hozzájárulnak a mondatok jelentéséhez' (STAInTON, 1996, 164). Putnam (1981, 2. fejezet és függelék) véges mondathalmazok referenciális átértelmezhetőségéről szóló tétele e meghatározatlansági tézist terjeszti ki azon elméletekre, melyek szerint a jelentés nem más, mint a szavak jelölete, referenciája.

E tézis első hallásra elég meglepően hangzik. A szótanulást vizsgálva nem nagyon jut eszünkbe az az elméleti lehetőség, hogy egyedi szavaink (itt most elsősorban a predikatív jellegủ kifejezésekre, köznevekre, igékre, melléknevekre gondoljunk) nem rendelkeznek pontosan megadható jelentéssel. Ez valószínűleg sokunk hétköznapi intuíciójával is ellenkezik. A meglepetést itt talán az okozhatja, hogy pszichológusként ösztönösen, kimondatlanul is valamiféle lexikai szemantikai megközelítés keretében vagyunk hajlamosak gondolkodni, és ez a megközelítés a fogalmi atomizmust foglalja magába. Azaz - talán - intuitíve hajlamosak vagyunk az atomista megközelítésre, annak feltevésére, hogy szavaink nagyobb nyelvi egységektől elszigetelten is rendelkeznek jelentéssel. Azonban, ha ebben az atomista szellemben gondolkodván mondjuk szótanulási kísérleteket végzünk, akkor vagy tévúton járunk, vagy kell lennie valamilyen hathatós érvnek, mely cáfolja a szójelentés meghatározatlanságáról szóló tézist.

Pusztán empirikus adatokkal nem megyünk sokra - le kell küzdenünk a meghatározatlansági tézis állította elméleti akadályt is. Nem elég például megfigyelésekre hivatkozni, melyek szerint nyelvtanuló gyerekek és nyelvet jól tudó felnőttek egyaránt produkálnak egyszavas közléseket, tanulnak egyedi szavakat, s ebből levonni a következtetést, hogy akkor a szavaknak mégiscsak kell legyen jelentésük. Ha mondjuk valaki egy adott helyzetben csak annyit mond „Lámpa”, ez a viselkedés a mi elméleti szempontunkból többféleképpen is értelmezhető. Lehet, hogy az illető a „Mi ez?” kérdésre válaszolt, és ekkor az egyszavas közlés hiányos mondatként fogható fel. A teljes mondat valahogy úgy szólna, hogy „Ez egy lámpa”, de a szövegösszefüggés lehetôvé teszi bizonyos elemek kihagyását. Ha azonban az előbbi egyszavas közlést egy kétéves gyerek teszi, rámutatván egy lámpára, de minden nyilvánvaló nyelvi kontextus nélkül (például ezzel kezdeményez egy közléssort), akkor felmerül egy másik értelmezés. Eszerint az egyszavas közlést nem az előzetes nyelvi kontextusból, hanem a kísérő nem nyelvi viselkedésböl (azaz itt a rámutatásból) lehet logikailag teljes közléssé kiegészíteni. A gyerek nyelvi és nem nyelvi viselkedésének (plusz a helyzetnek, melybe ágyazódik) együttesen tulajdoníthatunk egy logikai alakzatot, a példában egy szubjektum-predikátum formát. A gyerek a predikátumot mondja ki (lámpa), s hogy mire alkalmazza, azt a mutatás specifikálja. A szóbeli közlés és mutatás együtt a Lámpa(x) logikai formát testesíti meg, s a gyerek 
közlése izolált szóhasználatként értelmeződik, mivel nincs nyelvi kontextusba ágyazva. Hiányos mondatok esetében a kiegészítés és a logikai alakzat tulajdonítása az előzőleg elhangzott közlések alapján történik.

Ezek azonban eddig csak hipotézisek: lehet ugyanis úgy is érvelni, hogy a példabeli gyerek egyszavas közlése is hiányos mondat, nem pedig izolált szóhasználat; általánosítva: minden (látszólagos) izolált szóhasználat valójában hiányosmondat-használat. Ez a hiányosmondat-hipotézis (ellipsis hypothesis: STAINTON, 1993, 1999). Ha valóban minden (látszólagos) szóhasználat valójában mondathasználat ${ }^{3}$, akkor egy általánosabb nyelvfilozófiai tézishez érkezünk: állítások csak mondatok kimondásával tehetők, mondat alatti egységek kimondásával nem. Ennek a tézisnek az elfogadása nehézzé teszi az érvelést amellett, hogy szavak és összetett kifejezések izoláltan is rendelkeznek jelentéssel.

Ha viszont sikerül cáfolnunk a hiányosmondat-hipotézist, akkor megnyílik az út afelé az „ellentézis” felé, hogy állitásokat mondat alatti egységek izolált kimondásával is tehetünk. S úgy tűnik, a hiányosmondat-hipotézis ellen komoly érvek szólnak. Például az, hogy ha minden izolált szóhasználat hiányosmondat-használat, akkor nagyon sok szavunk (főneveink, igéink, mellékneveink) rengeteg, egymástól igen különböző jelentéssel fog rendelkezni. Ha a 'Piros' egyszavas közlés, bármilyen (pl. nyelvi közléssort kezdeményező) helyzetben jelenik is meg, hiányos mondatnak felel meg, mellyel kifejezhetem egyszer azt, hogy 'Ez a virág piros', másszor azt, hogy 'Ezt a falat legyen szíves pirosra festeni', s megint másszor azt, hogy 'Ez a zene intenzív piros élményt vált ki bennem', akkor a 'piros' szó legalább e három emített mondatnak megfelelő jelentéssel rendelkezni fog: e mondatok bármelyikének kifejezésére alkalmas önmagában, a nem nyelvi kontextus nélkül. Ha azonban úgy érvelünk, hogy a 'Piros' egyszavas közlés önmagában nem testesít meg propozicionális logikai formát, hanem csak a nem nyelvi kontextusból kiegészülve nyeri ezt el (azaz a 'Piros' közlés nem teljes mondat nullelemekkel), akkor megússzuk a sokértelműség kellemetlen következményét. A részleteket STAINTON (1993, 1999) tartalmazza.

Van tehát létjogosultsága a fenti gyerekpélda javasolt értelmezésének; mi több, ezen ellentézisnek már elméletileg jól védhető következménye lesz, hogy szavak és összetett kifejezések izoláltan is rendelkeznek jelentéssel. Ha ugyanis lehetséges egy izolált szóval vagy kifejezéssel (mely tehát csak nem nyelvi viselkedés plusz valamely szituáció kontextusába ágyazódik) állítást tenni, akkor igen nehéz elgondolni azt, hogy az izoláltan használt kifejezésnek semmilyen saját jelentéstartalma sincs, amely kiegészülhetne az adott kontextus által. Az erős nyelvfilozófiai hagyomány ellenére tehát a tétel, mely szerint szavak és összetett kifejezések önálló jelentéssel rendelkeznek, elméletileg jól megalapozható.

\footnotetext{
3 Stainton elemzése szerint a 'mondat'-nak itt három különféle értelmet is tulajdoníthatunk: szintaktikai, szemantikai és pragmatikai értelemben beszélhetünk mondatokról. A számunkra itt fontos mondanivaló azonban a részletek elhagyásával is érthetővé tehető.
} 


\section{REALIZMUS, TERMÉSZETI FAJTÁK ÉS A MEGISMERÉSTUDOMÁNY MAI KERETELMÉLETE (ELMÉLKEDÉS LAKI JÁNOS TANULMÁNYA ÜRÜGYÉN)}

Laki János tanulmánya Thomas Kuhn tudományfilozófiájából kiindulva kritikusan elemzi azt az ontológiai felfogást, mely a mai megismeréstudomány, illetve a kognitív pszichológia szempontjából központi jelentőségű. A szerző következtetése szerint e világkép, az úgynevezett metafizikai realizmus, illetve ennek részeként a természeti fajták elmélete nem tartható. A Laki által javasolt pozitív nézet nem áll messze az úgynevezett belső realizmustól (PUTNAM, 1981, 1989; LAKOFF, 1987); azaz egy enyhített realista felfogástól.

A természeti fajták elméletének kuhni kritikája a következő. Az még csak hagyján, hogy a realizmus szellemében feltételezzük, a tulajdonságok objektívek; az az állítás azonban, hogy az esszenciális tulajdonság-kontingens tulajdonság különbségtétel is objektív, már mindenképp túlzás. A tudomány fejlődése azt mutatja, hogy az elméletváltások pragmatikai szempontok (például a parszimónia elve, belső koherencia, új 'tudományos rejtvények' középpontba kerülése és megoldásuk igénye stb.) által motiváltak. Az elméletváltások megváltoztatják az egyes tulajdonságok relevanciáját a természeti fajták azonossága szempontjából. Például 1780 előtt a halmazállapotot az anyagtípus lényegi tulajdonságának tartották, s így a víz szükségképp kémiailag különbözött a vízgőztől. Később a halmazállapot egy pragmatikailag motivált elméleti döntés nyomán - kikerült az anyagfajta eszszenciális tulajdonságai köréből, s így, az új elméleti keretben, a víz, illetve vízgőz már azonos kémiai fajtát képeztek. Az ehhez hasonló elméleti választásokat nem alapozza meg az objektíve létező lényegi tulajdonságok felismerése: az esszenciális tulajdonságokat elméleteink konstituálják, ezek nem léteznek a világban tőlünk függetlenül.

A hasonlóság problémája a modern filozófiában alátámasztani látszik ezt az érvelést. A hasonlósági reláció meghatározatlansága mellett erős filozófiai érvek szólnak (gondoljunk Nelson Goodman vagy W. O. Quine ezzel kapcsolatos felfogására: arra, hogy tárgyak, jelenségek bármely halmazának elemei között találhatunk hasonlósági és különbözőségi viszonyokat is, szinte tetszés szerint). Ez azt jelenti, hogy pusztán a logika eszközeivel nem megyünk sokra, ha az objektív eszszenciákat akarjuk megtalálni. Az empirikus kutatás sem segít: mondjuk a biológia esete sokatmondóan sejteti, hogy a faj és egyéb rendszertani osztályok nem jellemezhetők olyan, szükséges és elégséges kritériumokkal, melyek az objektív esszencia 'episztémikus lenyomatainak' lennének tekinthetők. Ez nem is csoda, érvel Kuhn szellemében Laki: a hasonlóság megítélése a közös kognitív tréningen alapul. Hasonlóan 'behangolt' észlelő rendszerek, illetve hasonló fogalmi rendszerek (azaz: hasonló megismerők) ítéleteli egyezni fognak abban, hogy milyen külvilági entitásokat tartanak hasonlónak. A hasonlóság kognitíve konstruált reláció, s mint ilyen, attól függ, hogy működik a megismerő rendszer.

Az eddigiek egy meglehetősen radikális relativista felfogást sugallhatnának: az, hogy milyen fogalmi rendszereket alkotunk, s hogyan alkalmazzuk ezeket a világra, szinte teljesen önkényes, a külső valóság által nem korlátozott. Ez természete- 
sen túlzás. Bár Laki szerint igaz az, hogy a világnak számos, egymástól különböző és egyaránt helytálló fogalmi modellje lehetséges, arról szó sincs, hogy bármilyen fogalmi rendszer megfelelne - legalábbis a tudomány céljaira. A természet vagy külvilág egy általános empirikus nyomást gyakorol a kísérletező tudósokra: a belső realista Putnammel azt is mondhatjuk, hogy amikor valamilyen elméleti rendszert hozunk létre, s ezt kísérleti úton vizsgáljuk meg, kérdést intézünk a természethez; $\mathrm{s}$ a választ a természet adja, nem mi. Bizonyos elméletek tapasztalatilag támogathatóak, míg mások nem. Mivel azonban a valóság nem olyan élesen tagolt, „kategóriákkal előre bebútorozott”, mint azt a metafizikai realizmus sugallja, nem csak egyetlen helyes, azaz tapasztalatilag támogatható tudományos elmélet lehetséges. A környezet általános empirikus nyomása azért áll fenn, mert a tulajdonságok valamiképpen mégiscsak objektívek (a nekik az elméletekben tulajdonított relevanciaértékek azonban nem).

A továbbiakban szeretnék Laki gondolatmenetéhez néhány rövid megjegyzést hozzáfüzni. Először is a természeti fajták elmélete elleni, Kuhn szellemében fogant érvek jó része Kripke és a metafizikai realista Putnam szellemében elég hathatósan megválaszolható. Goodman indukcióval kapcsolatos rejtélyére létezik válasz a természeti fajták elméletében; s Kuhnnal nem ért egyet mindenki a tudomány konvergens, kumulatív fejlődésének elvetésében. Ha pedig a kumulatív tudományfejlődés mégiscsak fenntartható elgondolás, azaz a versengő elméletek között mindig van értelme a legjobbat keresni, akkor ismét felmerül az a modell, mely szerint a legjobb elmélet az, amelyik a legjobban illeszkedik a valóság szerkezetéhez. Kripke valószínűleg azt mondaná, hogy a választás, mely szerint a víz és a (víz)gőz különböző kémiai anyagok, egyszerủen téves. ${ }^{4}$ Hasonló ez ahhoz, hogy bár az ókori görögök úgy tartották, a világot négy alapelem alkotja, az, amit ők egy alapelem eseteiként soroltak fel, nem alkotott egyetlen természeti típust objektíve heterogén kategória volt. Itt tehát a világ téves fogalmi szeleteléseiről van szó. Ehhez képest a molekuláris kémia a természet 'valódi mélystruktúrájának' felismerése felé tett lépés. A természet objektív strukturálódási szintjeit véve alapul, a kémiai, molekuláris szint - mely az anyagfajtákat kijelöli - nem tartalmazza a halmazállapotot mint esszenciális tulajdonságot.

Lakinak az az észrevétele, hogy „Putnam figyelmen kívül hagyja az 'azonos természetư' reláció meghatározatlanságát” (295. old.) szintén megválaszolható. A keményfejű realista számára az 'azonos természeti fajta' reláció meghatározott, de episztémikusan nem transzparens; épp ezért kell tudományos kutatás tárgyává tenni. Az erős realizmus ellenzői, például Goodman számára a hasonlóság vagy azonos természet relációja valóban meghatározatlan.

\footnotetext{
4 Azaz: érzésem szerint a Laki említette víz-vízgőz példában az elméleti váltás, mely 'kivette' a halmazállapotot az esszenciális tulajdonságok köréből, értelmezhető tévedés kiküszöbölésének, még akkor is, ha nem volt egyetlen konkrét empirikus felfedezés, mely közvetlenül motiválta volna ezt az elméletváltási lépést. Általában igaz az, hogy az elmélet- vagy paradigmaváltások egyike sem köthető egyetlen konkrét empirikus felfedezéshez.
} 
Laki szerint (295. old.): „Putnam modellje csakis akkor müködne, ha tartozna hozzá egy olyan metakritérium-rendszer, melynek segítségével objektív döntéseket lehetne hozni arról, hogy a lehetséges tulajdonságok közül melyiket kell eszszenciálisnak, a fajtát meghatározónak tekinteni. Ilyen kritériumot azonban Putnam természetesen nem tud adni..." Azaz, szól az érv, ha nem tudunk előzetes metakritériumot adni a lényegi tulajdonságok kiválogatására, akkor nem beszélhetünk a lényegi tulajdonságok mint megismerésfüggetlenül adottak felismeréséről; tehát csak az antirealista vagy enyhített realista út marad elfogadható.

Kripke tagadná ezt, és azt mondaná, hogy a metakritérium-rendszer túlzott elvárás a természeti fajták elméletével szemben (angolul question-begging: a realizmuséival ellenkező előfeltevések elfogadása, s nem következményei tarthatatlanságának vagy inkoherenciájának demonstrálása). Hiszen előre megmondtuk - válaszolhatná Kripke -, hogy a lényegi tulajdonságok nem nyilvánvaló módon adottak megismerésünk számára (azaz nem episztémikusan transzparensek). Az esszenciákat, a természet szerkezetét fel kell fedezni; s hogyan lehetne akkor felfedezésük előtt egy általános elméleti keretet adni arról, hogy mi a lényegi tulajdonság? Mellesleg, egy igen általános metakritériumra még futja is a Kripke-Putnam elméletből. Eszerint az esszenciális tulajdonságoknak a természet objektív strukturálódási szintjeihez kell igazodniuk, s nem keresztezni e szinteket, azok ellenében haladni. Ennél többet végképp nem lehet mondani anélkül, hogy tudományos vizsgálódás segítségével tisztáznánk, hogyan is néznek ki a természet objektív szerveződési szintjei (melyek létét a realizmus kiindulásképpen felteszi).

Tanulmányában Laki János nem tér ki arra, hogy a természeti fajták elmélete miért oly drága a számítógépi funkcionalista, információfeldolgozó pszichológia számára. A válasz e kérdésre az, hogy az úgynevezett szemantikai externalizmus - a számítógépi ihletésủ kognitív pszichológia jelentéselmélete - előfeltételezi a természeti fajták elméletét. Ha a természeti fajták elmélete hibás, akkor a számítógépmetafora nem képes magyarázatot adni a szójelentés problémájára - azaz arra, hogyan lehetséges az, hogy a fejünkben lévő bizonyos idegi állapotok valamely önmagukon túli (jellegzetesen külső környezeti) dologra utalnak, azt jelentik! Minthogy azonban eddig senkinek sem sikerült a metafizikai realizmussal szemben megsemmisítő érvet találnia (noha sokan elégedetlenek e filozófiai felfogással: lásd PUTNAM, 1981, 1989; LAKOFF, 1987), nyitva az út a szemantikai externalizmus amúgy igen részletesen kidolgozott elmélete előtt.

\section{ZÁRÓ MEGJEGYZÉSEK}

E recenzió végső következtetése álljon összhangban a könyv sugallta konklúzióval: azzal tehát, hogy az erős, szélsőséges relativista nézet nem tartható, s a megismerés közös emberi természet diktálta egyetemes jegyeire újra és újra rábukkanhatunk, ha egy kicsit a felszín mögé nézünk. Ez tehát valamiféle „arany középutas” álláspont, de olyan formában, hogy az „egyetemes mélyréteg” felett nyelv- és kultúrafüggő, különböző felszíneket találunk (erre utal Pléh Csaba változatok egy témára megfogalmazása is). 
Talán Fodornak igaza van (a 46-47. oldalon szereplő idézetben) a következő értelemben. A whorfi (és első látásra Wittgenstein nézeteiből is származtatható) erős relativizmus kimondatlanul is negatív doktrína: implicite tagadja ugyanis azt, hogy lenne valamilyen érdekes értelemben vett közös emberi természet - azt tehát, hogy hasonítunk is egymásra, nem csak különbözünk. A mai megismeréstudomány univerzalizmusa érvényesíti a közös emberi természet fogalmát. Ezzel együtt semmi esetre sem zárja ki a különbségek lehetőségét. Felszíni különbségek mindenképpen lehetségesek, s ezek kétségkívül lehetnek igen nagyok is (kínai és magyar nyelv; zen-buddhista és angolszász-elemző észjárás stb.). Véleményem szerint arról is szó van itt, hogy a dolog természetéből fakadóan az univerzalizmus nem is lehet olyan szélsőséges doktrína, mint a relativizmus. Ugyanis a nyelvikulturális különbségek mindenki számára azonnal nyilvánvalóak - épeszű ember ezt nem tagadja. Az univerzalista-relativista vita valójában arról szól, hogy mit találunk akkor, ha e felszín mögé nézünk. Az univerzalista szerint a különbségek felszíne mögött az egyetemes emberit találjuk, ám ennek kimutatásához alaposabb megfigyelés, érvelés szükségeltetik. Addig elmenni, hogy csak a közös háttér léte$z i k$, a nyelv- és kultúrafüggő felszín merő illúzió, abszurdum. Pedig ez lenne a szélsőséges univerzalizmus: lényegében a bábeli zűrzavar nyílt tagadása. A szélsőséges relativista szerint viszont még ha a felszín mögé nézünk is, akkor sem találunk mást, mint mélyreható különbségeket. S bár első hallásra az erős relativista álláspont hangozhat meggyőzően, az alaposabb vizsgálat kimutatja túlzó voltát.

Általánosságban a mai megismeréstudománynak két alapvető és egymástól független központi gondolata is támogatja az univerzalista következtetést, és ezek közül az egyik, méghozzá a nehezebben elvethető, is elég. Egyrészt belső felépítésünk, megismerő rendszerünk működése egyetemes vonásokat mutat. Másrészt, a már tárgyalt realista metafizika szerint közös világunk alakítja világképünket, s nem világképünk alakítja világunkat. Jól ismert, hogy viszonyul a wittgensteini filozófia ezekhez: a gondolkodás nem belső folyamatok, hanem viselkedés kérdése (azaz nem tulajdonít jelentőséget az első tényezőnek), másrészt a realizmussal is szembenáll. Így már megnyílhatna az út a relativizmus felé - főleg ha meggyőzően tudnánk érvelni amellett, hogy nyelven túlmutató univerzálék valóban nem léteznek (lásd Neumer Katalin tanulmányait).

A másik irányból nem találkozunk annyi megszorítással: megismerő rendszerünk egyetemes jegyei plusz a realista világkép együtt még mindig nem nyilvánvalóan inkompatibilisek a meglehetősen mélyreható nyelvi-kulturális különbségek gondolatával. Vegyük észre azt is, hogy ha a metafizikai realizmust elvetjük, és egy enyhített, úgynevezett 'belső' realizmust fogadunk csak el (PUTNAM, 1981, 1989; LAKOFF, 1987; érzésem szerint Laki János is e nézettel rokonszenvezik tanulmányában), az univerzalizmus gondolata még mindig érthető és magyarázható marad megismerő rendszerünk egyetemes jegyei segítségével. Azaz: bár észlelésünk vagy fogalmaink segítségével sokféleképpen szeletelhetjük a világot, és ezek között a szeletelések között nincs egyetlen helyes, mégis közös belső felépítésünk folytán nyelv- és kultúrafüggetlen hasonlóságok figyelhetőek meg abban, ahogy szeletelünk. Szép példa itt a színeké: erős érvek és tapasztalati adatok szólnak amellett, hogy a szín, eltérően az alaktól, nem objektív tulajdonság: a tárgyak színe nem 
létezik az észlelőrendszerektől függetlenül. Mégis, mint a Berlin és Kay-féle vizsgálatból, s ennek utóéletéből tudjuk (BERLIN, KAY, 1969; HARDIN, MAFFI, 1997; KAY, McDANiEL, 1997), a színek rendszere embernél egyetemes jegyeket mutat. Bár a tárgyak színek szerinti felosztása önkényes, mégis alapvetően egyetemes - az emberi látórendszer sajátossága. Ehhez adódik még hozzá az, amit az enyhített realizmus is kiköt (lásd Laki tanulmányát), nevezetesen, hogy bár több mint egy helytálló fogalmi leképezése lehet világunknak, azért messze nem igaz az, hogy bármilyen fogalmi rendszer helytálló lenne.

\section{IRODALOM}

Berlin, B., KaY, P. (1969) Basic Color Terms: Their Universality and Evolution. University of California Press, Berkeley-Los Angeles

Dennett, D. (1991) Consciousness Explained. Little Brown, New York

Dummetт, M. (1981) The Interpretation of Frege's Philosophy. Duckworth, London

Frege, G. (1978) Foundations of Arithmetic. 2nd Revised Edition. Basil Blackwell, Oxford

Hardin, C. L., Maffi, L. (eds) (1997) Color categories in thought and language. Cambridge University Press, Cambridge

Kay, P., McDaniel, C. K. (1997) The Linguistic Significance of the Meanings of Basic Color Terms. In Alex Byrne-David R. Hilbert (eds) Readings on Color. Vol. 2. (The Science of Color), 399-441. MIT Press, Cambridge

Lakoff, G. (1987) Women, Fire, and Dangerous Things. The University of Chicago Press

Neale, S. (1990) Descriptions. MIT Press, Cambridge

Putnam, H. (1981) Reason, Truth, and History. Cambridge University Press, Cambridge

Putnam, H. (1989) Representation and Reality. MIT Press, Cambridge

Quine, W., O. (1960) Word and Object. MIT Press, Cambridge

Stainton, R. (1993) Non-sentential Assertions. Ph. D. Thesis, Department of Linguistics and Philosophy, Massachusetts Institute of Technology

Stainton, R. (1996) Philosophical Perspectives on Langugae. Broadview Press

Stainton, R. (1999) The Meaning of 'Sentences'. Kézirat, Carleton University, Ottawa 